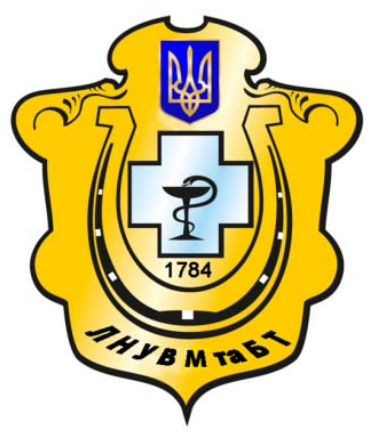

Науковий вісник Львівського національного університету ветеринарної медицини та біотехнологій імені С.З. Гжицького

Scientific Messenger of Lviv National University of Veterinary Medicine and Biotechnologies named after S.Z. Gzhytskyj

doi:10.15421/nvlvet7528

ISSN 2519-268X print

ISSN 2518-1327 online

$\underline{\text { http://nvlvet.com.ua/ }}$

УДК 664.32:687.55

\title{
Використання баранячого жиру у виробництві косметичних засобів
}

\author{
I.C. Ромашко, У.P. Драчук, I.M. Басараб \\ mysh@ukr.net, ul.drachuk@gmail.com, iryna.basarab@gmail.com
}

Львівський національний університет ветеринарної медицини та біотехнологій імені С.3. Гжицького, вул. Пекарська, 50, м. Львів, 79010, Украӥна

Косметична галузь нині розвивається стрімкими темпами. Особливу увагу привертають товари, отримані з натуральної сировини. Для виробництва косметичних виробів використовують різні жирові основи, а саме тваринні, рослинні та мінеральні жири, а також жироподібні речовини. Їх використовують як в чистому, так і в комбінованому вигляді. Тваринні жири є сировиною для виготовлення продукиії різного спрямування: харчового, медичного, косметичного, а також технічного. Характерною особливістю кожного жиру є його склад та властивості, щуо залежать від походження, рачіону тварини та ї̈ віку.

Одним з найбільш поширених компонентів тваринного походження у рецептурах косметичних виробів є ланолін, відомий як шерстяний жир, щьо отримують під час виготовлення овечої шерсті. Баранячий жир - джерело природного ланоліну - здавна відомий своӥми корисними властивостями, особливо курдючний жсир, що відрізняється високою чистотою $і \epsilon$ цінною харчовою та фармацевтичною сировиною. Курдючний жир - не лише чудовий продукт харчування та лікувальний засіб при застудах чи проблемах із суглобами, а й засіб для підтримання здоров'я і краси шкіри, волосся та нігтів.

У статті проаналізовано світовий досвід використання тваринних жирів у косметології. Показано доиільність застосування курдючного жиру у виготовленні косметичних виробів. Завдяки присутності ланоліну, органолептичним та фізикохімічним характеристикам курдюк можна використовувати як основу для виготовлення косметичних кремів. Це перспективний напрямок для розвитку украӥнської косметологї.

Ключові слова: тваринні жири, баранячий жир, курдюк, креми, ланолін, косметика.

\section{Использование бараньего жира в производстве косметических средств}

\author{
И.С. Ромашко, У.Р. Драчук, И.М. Басараб \\ mysh@ukr.net, ul.drachuk@gmail.com, iryna.basarab@gmail.com
}

Львовский национальный университет ветеринарной медицины и биотехнологий имени С.3. Гжицкого, ул. Пекарская, 50, г. Львов, 79010, Украина

Косметическая отрасль сегодня развивается стремительными темпами. Особое внимание привлекают товары, полученные из натурального сырья. Для производства косметических изделий используют различные жсировые основы, а именно животные, растительные и минеральные жиры, а также жироподобные вещества. Их используют как в чистом, так и 8 комбинированном виде. Животные жиры являются сырьем для изготовления продукиии различного направления: пищевого, медицинского, косметического, а также технического. Характерной особенностью каждого жира является его состав и свойства, зависящие от происхождения, рачиона животного и его возраста.

Одним из наиболее распространенных компонентов животного происхождения в рецептурах косметических изделий является ланолин, известный как шерстяной жир, получаемый при изготовлении овечьей шерсти. Бараний жир - источник природного ланолина - издавна известен своими полезными свойствами, особенно курдючный жир, отличаюшийся высокой чистотой и являющийся ценным пищевым и фармацевтическим сырьем. Курдючный жир - не только замечательный продукт питания и лечебное средство при простудах или проблемах в суставах, но и средство для поддержания здоровья и красоты кожи, волос и ногтей.

Citation:

Romashko, I., Drachuk, U., Basarab, I. (2017). Use of sheep fat in the production of cosmetics. Scientific Messenger LNUVMBT named after S.Z. Gzhytskyj, 19(75), 140-143. 
В статье проанализирован мировой опыт использования животных жиров в косметологии. Показана целесообразность применения курдючного жира в изготовлении косметических изделий. Благодаря присутствию ланолина, органолептическим и физико-химическим характеристикам курдюк можно использовать как основу для изготовления косметических кремов. Это перспективное направление для развития украинской косметологии.

Ключевые слова: животные жиры, бараний жир, курдюк, кремы, ланолин, косметика.

\title{
Use of sheep fat in the production of cosmetics
}

\author{
I. Romashko, U. Drachuk, I. Basarab \\ mysh@ukr.net, ul.drachuk@gmail.com, iryna.basarab@gmail.com
}

\begin{abstract}
Lviv National University of Veterinary Medicine and Biotechnologies named after S.Z. Gzhytskyi, Pekarska Str., 50, Lviv, 79010, Ukraine
\end{abstract}

\begin{abstract}
Cosmetic industry is developing rapidly. Particular attention is drawn to products derived from natural ingredients. For the production of cosmetic products using different bases fat, such as animal, vegetable and mineral fats and fat-like substances. They are used both in pure and in combined form. Animal fats are raw materials for the manufacture of different products: food, medical, cosmetic and technical. Characteristic features of each fat are its compounds and qualities, which depend on the origin and diet of the animal and its age.

Lanolin is one of the most common components of animal origin in cosmetic formulations products. It is known as wool fat. It is produced in the manufacture of sheep's wool. Sheep fat contains lanolin and is also known for its healthy properties. Tail fat has a high purity and it is a valuable food and pharmaceutical raw material. Tail fat is not only fine food and a medical product, which is used for colds and for problems with joints, but also as a remedy for health and beauty of skin, hair and nails.

The world experience of using animal fats in cosmetology is analyzed in this article. The expediency of using tail fat in the manufacture of cosmetic products is shown. The tail fat can be used as a base form of the cosmetic creams, because of the presence of lanolin, its organoleptic properties and chemical features. This is a promising direction for the development of Ukrainian cosmetolo-
\end{abstract} gy.

Key words: animal fat, sheep fat, tail fat, creams, lanolin, cosmetics.

\section{Вступ}

Жири тваринного походження - це унікальні природні, цілковито натуральні речовини, які формуються в організмі тварин. Їх позитивний вплив на людський організм виявляється у лікувальній та косметологічній дії на шкіру, волосся і тіло, вони підвищують імунітет організму та активізують його захисні сили. Тваринні жири здавна застосовуються людством також для лікування і профілактики різних захворювань. Основною сферою використання тваринних жирів, безперечно, залишається харчова промисловість. Але, крім виробництва продуктів харчування, жири є сировиною в медичній, косметичній і технічній галузях. Їх застосовують як в чистому вигляді, так i у вигляді сумішей (Berkov and Berkova, 2006; Pertsevyi et al., 2006; Andreeva, 2007; Honcharenko, 2016).

Говорячи зокрема про косметологію, важливим також є те, що тваринні жири характеризуються достатньо сильними природними антиоксидантними властивостями. Це використовується в косметичній науці при створенні, наприклад, ефективних засобів для відновлення пружності шкіри обличчя, зони під очима, шиї, зони декольте, а також засобів для зміцнення і оздоровлення волосся та нігтів. Перевагою тваринних жирів є гіпоалергенність, оскільки вони (за винятком випадків індивідуального неспийняття) не викликають реакцій з боку шкіри (Bulgakova, 2003; Peshuk et al., 2007; Holub et al., 2016). Температурнов'язкісні характеристики тваринних жирів дозволяють отримувати на їх основі цілий спектр продукції лікувального та косметичного призначення - мазі, креми, маски, бальзами тощо. I це лише незначна частка потенційних можливостей застосування жирів тваринного походження. Актуальним напрямком наукової косметології $\epsilon$ пошук ефективної натуральної сировини та створення нових косметичних засобів з іiі використанням.

Метою досліджень було проаналізувати світовий досвід використання тваринних жирів у косметології та встановити доцільність застосування курдючного жиру для отримання косметичних кремів.

\section{Результати та їх обговорення}

3 великого загалу відомих і непогано вивчених сьогодні твердих жирів особливої уваги заслуговує баранячий. Це унікальний, передовсім, харчовий продукт, найбільш поширений в культурах Кавказу та Середньої Азії.

Відмінні від інших властивості баранячого жиру визначаються його особливим складом. Він містить насичені (пальмітинову - 26\%, стеаринову - 14\%, міристинову - 3\%), мононенасичені (олеїнову $-47 \%$, пальмітоолеїнову - 3\%) і поліненасичені (лінолеву $3 \%$, ліноленову - 1\%) жирні кислоти.Топлене бараняче сало характеризується присутністю полівітамінів, бета-каронтину, що захищає організм від радіаційного опромінення, а також вітамінів $\mathrm{B}_{1}$ та Е, важливих для нормального обміну речовин. В баранячому жирі $\epsilon$ такі корисні для нашого організму мінеральні компоненти, як Залізо, Фосфор, Цинк, Кальцій, Натрій, Магній, Мідь, Селен.

Користь баранячого жиру в тому, що незважаючи на високу калорійність (близько 900 ккал на 100 г), він прекрасно засвоюється, при цьому швидко поповнює енергетичний запас організму, підвищує імунітет, 
сприяє швидкому загоєнню ран, активізує мозкову i кровоносну діяльність, покращує пам'ять і процеси мислення, тонізує функціональність шлунку, роботу нервової системи, подовжує молодість, позитивно діє на стан шкіри, нігтів та волосся, а також навіть в наш час залишається відмінним самостійним засобом при застуді й кашлі, допомагає у лікуванні хворих суглобів, жировиків та варикозів.

Баранячий жир $є$ характерною родзинкою страв кавказької та східної кухні, тимчасом як європейці рідко його використовують. Цей продукт отримують 3 внутрішнього сала і курдюка - жирового відкладення у вигляді мішка в задній частині туші овець і баранів особливої (курдючної) породи.

Вівчарство відоме ще з часів неоліту, а в Україні воно поширене 3 кінця 18 ст. Розвивалось переважно в багатих на пасовища районах - на полонинах Карпат, у лісостепу, де багато сіножатей і паші, в Криму і Бесарабії. Продукція вівчарства задовольняла основні господарські потреби людей - давала грубу вовну для виробництва домашнього сукна, м'ясо, жир, молочні продукти й удобрення для грунту. Вівчарство могло б стати прибутковою ланкою в сільському господарстві України, якби ми навчились використовувати наші потенційні можливості, а саме 300-літній практичний досвід українських вівчарів, здобутки вітчизняної генетики у сфері вдосконалення існуючих і створення нових порід та типів овець, а також сотні тисяч гектарів невикористаних пасовищ Азово-Чорноморського коридору Степу від Дунаю до Керчі, Лісостепу та Полісся.

Загалом за свою історію вівчарство в Україні переживало злети і падіння, але сьогодні ситуація в цій сфері впевнено, хоч і повільно, рухається в позитивному напрямку. Тому молоді та підприємливі люди можуть скористатися цим, впроваджуючи у виробництво продукцію вівчарства, в тому числі й косметичного спрямування. Баранячий жир широко застосовується світовими брендами косметологічної індустрії як основа кремів, масок і бальзамів для омолодження шкіри. Відомі креми на основі баранячого жиру, які розгладжують зморшки, захищають обличчя і руки в зимовий час.

Курдючний жир і нутряне (внутрішнє) сало - не одне і те ж. Специфічна особливість баранячого жиру - тугоплавкість (температура топлення $50{ }^{\circ} \mathrm{C}$ ) і своєрідний запах, але курдюк більш легкоплавкий з приємним ароматом і смаком. Курдючне сало є чудовим засобом для підтримки краси і здоров'я шкірних покривів, оскільки збагачене природним ланоліном. Корисні властивості даної жироподібної речовини були відкриті ще древніми греками і римлянами. Вони в ті часи використовували неочищений ланолін, що і було ïx помилкою, адже ця речовина містила в собі бруд та інші шкідливі речовини. Сучасні технології дозволяють отримати чистий продукт, що також називають тваринним воском.

Ланолін має в'язку консистенцію. Він може бути різних відтінків, від світло-жовтого до темнокоричневого. Оскільки ланолін $є$ жиром, запах його не можна назвати приємним, однак цю особливість су- часна косметологія вміє корегувати. 10\% складу ланоліну становлять стероли, до яких належить і холестерол. За фізичними властивостями ланолін нагадує сало шкіри людини (точніше, мультиламелярні структури ланоліну типові для рідких кристалів людської шкіри), цим і пояснюється його ефективність як косметичного засобу. Температура плавлення ланоліну невисока - від 36 до $42{ }^{\circ} \mathrm{C}$. Також він є хорошим емульгатором, оскільки здатний утримувати вдвічі більшу за свою вагу кількість води.

Одним із сучасних світових трендів є органічна продукція, поряд з органічним стилем життя, що передбачає переважне використання натурального одягу, їжі, меблів і косметики. Поняття «органічні» прийшло 3 харчової промисловості, де органічними називаються продукти або їх компоненти, які не просто мають природне походження, а й вирощені без використання будь-яких хімічних добрив в екологічно чистих умовах. Процес переробки органічних продуктів повинен відповідати жорстким стандартам, тому не кожен натуральний продукт як харчовий, так i косметичний, можна назвати органічним.

Характерною відзнакою органічної косметики $є$ позначки «Organic» і «Вio», що означає відсутність у складі синтетичних та сумнівних щодо корисності компонентів. Етикетка оргкосметики повинна містити повний перелік інгредієнтів та зазначення сертифіката. Сьогодні немає узгодженої думки світових виробників косметики у прийнятті єдиного стандарту, який визначив би поняття органічної, еко- або біокосметики, тому в різних країнах є своя сертифікація. Цікаво зазначити, що європейська косметика класу «Organic» не дозволяє використання тваринних жирів та їх компонентів. Однак косметичні вироби, до складу яких входять жири тваринного походження, з кожним роком набувають все більшої популярності та отримують схвальні відгуки споживачів.

В даному контексті не є винятком велика частка ланолінвмісної продукції, що давно і позитивно себе зарекомендувала в багатьох сферах людського побуту. Їх альтернативним варіантом можуть стати вироби 3 використанням баранячого, а власне, курдючного жиру, як джерела природно чистого ланоліну. Сдиною суттєвою перешкодою може виявитись ціна курдюка, яка співмірна 3 ціною баранини (або й вища за неї). Однак на кожен товар є свій купець, особливо, коли якість займає передові позиції. Для України досвід виробництва косметичних кремів на основі курдючного жиру поки що новий, хоч світові косметичні компанії ведуть роботу в цьому напрямку, i досить успішно.

Нині в косметичній індустрії велика кількість найрізноманітнішої косметики, і вся вона має свій вплив на шкіру. При виборі засобів потрібно звертати увагу не тільки на свої проблеми, а й підбирати товар з урахуванням самої шкіри. Вся косметика 3 тваринними жирами спрямована на досягнення основних позитивних характеристик: зволоження, пом'якшення, живлення та захист. Засоби по догляду за шкірою, в основі яких - курдючний жир, поки що належать до нових тенденцій, тому що з'явилися не так давно (в промисловому виробництві). Можливо, саме зараз настав той 
момент, коли курдючний жир почав користуватися попитом, що пояснюється великою кількістю цінних компонентів у його складі, поживні властивості яких, на думку фахівців, перевершують навіть деякі олії в рази. Цим забезпечується зволоження тканин протягом як мінімум двох діб та спостерігається сповільнення всіх процесів старіння. $Є$ країни, наприклад Японія та Монголія, які створюють на основі цього компонента засоби, що допомагають боротися 3 серйозними шкірними захворюваннями.

\section{Висновки}

В результаті проведення аналізу сучасних тенденцій щодо використання тваринних жирів у виготовленні косметичних виробів підтверджено, що засоби для шкіри, які містять у своєму складі жири тваринного походження, покращують стан шкіри, волосся та нігтів. Ознакою якості кремів на основі твердих жирів $\epsilon$ їх добре поглинання шкірою. Креми $з$ додаванням ланоліну підходять для різних типів шкіри і навіть для юнацької, оскільки борються з вугровими висипами і знімають запалення, активуючи процес відновлення синтезу церамідів, завдяки чому відбувається захист шкіри, та пригнічується розвиток бактерій. Альтернативою сировини для отримання таких засобів може стати курдючний жир - природне джерело ланоліну. Креми на основі курдючного жиру будуть ефективними у холодну пору року завдяки активізації роботи кровоносних судин та природного зігріваючого ефекту. Загалом, косметичні вироби на основі курдючного жиру є перспективними учасниками світової косметичної індустрії.

\section{Бібліографічні посилання}

Berkov, B.V., Berkova, G.I. (2006). Natural'naja kosmetika i omolazhivajushhie sredstva - put' $\mathrm{k}$ prodleniju molodosti. M.: Feniks (in Russian).

Andreeva, E.A. (2007). Maski, kremy, bal'zamy v domashnih uslovijah. H.: Mir knigi (in Russian).

Bulgakova, I.V. (2003). Kosmetologija ot A do Ja. Rostov $\mathrm{n} / \mathrm{D}$ : Feniks (in Russian).

Holub, L.S., Rudnieva, L.L., Lutsenko, M.V. (2016). Vyrobnytstvo kharchovykh tvarynnykh zhyriv. Navchalnyi posibnyk dlia studentiv vyshchykh navchalnykh zakladiv. Dnipropetrovsk: DVNZ UDKhTU (in Ukrainian).

Pertsevyi, V.F., Kamsulina, N.V., Kolesnikova, M.B., Yancheva, M.O., Hurskyi, P.V., Tishenko, L.M. (2006). Tekhnolohiia produktsii kharchovykh vyrobnytstv. Navchalnyi posibnyk. Kharkiv: KhDUKhT (in Ukrainian).

Honcharenko, I.V. (2016). Tekhnolohii pobichnoi produktsii tvarynnytstva. Konspekt lektsii. K.: Tsentr uchbovoi literatury (in Ukrainian).

Peshuk, L.V., Bavika, L.I., Demidov, I.M. (2007). Tekhnolohiia parfumerno-kosmetychnykh produktiv. Navchalne vydannia. K.: Tsentr uchbovoi literatury (in Ukrainian).

Стаття надійшла до редакиії 28.03.2017 